Рекомендована д. фрармац. наук, профр. Т. А. Грошовим

УДК 615:061.2]:614.2(100):346.1

DOI 10.11603/2312-0967.2017.3.8110

\title{
СУЧАСНИЙ СТАН ЗАКОНОДАВЧОГО ЗАБЕЗПЕЧЕННЯ САМОРЕГУЛЮВАННЯ ГОСПОДАРСЬКОЇ ДІЯЛЬНОСТІ ТА ПЕРСПЕКТИВИ САМОРЕГУЛЮВАННЯ І ДЕРЖАВНОГО РЕГУЛЮВАННЯ ФАРМАЦЕВТИЧНОЇ ДІЯЛЬНОСТІ В УКРАЇНІ
}

\author{
(с) Б. П. Громовик, О. Б. Панькевич
}

\author{
Львівський національний медичний університет імені Данила Галицького \\ hromovyk@gmail.com, pankevych.Iviv@gmail.com
}

\begin{abstract}
Мета роботи. Аналіз сучасного стану законодавчого забезпечення процесів саморегулювання (СР) господарської діяльності та перспектив СР і державного регулювання (ДР) фрармацевтичної діяльності.

Матеріали і методи. Матеріалом дослідження були нормативно-правові акти, що стосуються СР. Для вирішення поставленої задачі були застосовані методи дослідження: системний, аналізу, порівняння, формалізації, узагальнення та моделювання.

Результати й обговорення. Вивчення нормативно-правової бази у сфрері СР господарської діяльності в Україні показало, що дане положення тією чи іншою мірою закріпилося на ринку фрінансових послуг та його сегментів, у сорері землеустрою, архітектурної діяльності, діяльності оцінювачів, адвокатів, нотаріусів та аудиторів. При цьому в інших видах господарської діяльності, зокрема у фрармацевтичній сфері, СР не знайшло належного законодавчого закріплення. Показано сучасний стан регулювання фрармацевтичної діяльності за участю громадських організацій та громадських рад при центральних органах виконавчої влади, а також перспективу її СР.

Висновки. На підставі аналізу нормативно-правової бази досліджено особливості СР різних видів господарської діяльності в Україні. Змодельовано взаємодію інститутів громадянського суспільства 3 органами ДР та саморегулюючими організаціями щодо фармацевтичної діяльності від стану «як є» до стану «як бути».
\end{abstract}

Ключові слова: господарська діяльність; саморегулювання; державне регулювання; фрармацевтична діяльність.

Вступ. Правовий господарський порядок в державі ґрунтується на чинному законодавстві, зокрема на ст. 5 Господарського кодексу України, відповідно до якої він формується на основі оптимального поєднання ринкового саморегулювання (СР) економічних відносин суб'єктів господарювання та державного регулювання (ДР) макроекономічних процесів [1]. У свою чергу, профресійне СР базується на ст. 12 і 13 Цивільного кодексу України, згідно 3 якими особа здійснює свої цивільні права вільно, на власний розсуд у межах, наданих їй договором або актами цивільного законодавства [2]. При цьому фрармацевтичне СР - це добровільна ініціатива, яка дає змогу суб'єктам господарської діяльності у фрармацевтичному секторі галузі охорони здоров'я та/або учасникам фрармацевтичної діяльності розробляти і встановлювати стандарти і правила вказаної діяльності в інтересах своїх членів та споживачів лікарських засобів і фрармацевтичних послуг [3]. Утім несприймання центральними органами державної влади (ЦОВВ) рівного партнерства із суб'єктами фрармацевтичного СР і небажання передати частину повноважень щодо СР у системі організації та надання належних фрармацевтичних послуг нині призводить до недієвості інституту фрармацевтичного СР [4]. Відшукати мудре співвідношення між ДР і фармацевтичним СР - одне з ключових завдань розвитку фармацевтичного сектора галузі охорони здоров'я.

Дослідження теоретико-практичних засад ДР і СР учасників фрармацевтичного ринку (УФР) висвітлювалися у працях ряду вітчизняних науковців [3-8]. Незважаючи на наявність цих публікацій, проблемним залишається питання про місце і роль фрармацевтичного СР та його співвідношення $з$ ДР.

Матеріали і методи. Матеріалом дослідження були нормативно-правові акти, що стосуються СР. Для вирішення поставленої задачі були застосовані методи дослідження: системний, аналізу, порівняння, формалізації, узагальнення та моделювання.

Результати й обговорення. Вивчення чинного законодавства України у сфері СР господарської діяльності показало, що дане положення тією чи іншою мірою закріпилося на ринку фінансових послуг (РФП) та його сегментів, у сорері землеустрою, архітектурної діяльності, діяльності оцінювачів, адвокатів, нотаріусів та аудиторів. При цьому, як видно з даних таблиці 1 , поняття «саморегулівна організація (СРО)» визначається по-різному як 3 погляду суб'єктів, так і об'єктів СР. Варто зазначити, що на РФП діють лише три СРО і лише в межах фрондового його сегмента.

ISSN 2312-0967. Pharmaceutical review. 2017. № 3 
Організація роботи аптечних підприємств Organization of pharmaceutical structures' work

Таблиця 1. Особливості СР окремих видів господарської діяльності

\begin{tabular}{|c|c|}
\hline $\begin{array}{c}\text { Основні } \\
\text { характеристики }\end{array}$ & Їх суть \\
\hline 1 & 2 \\
\hline \multicolumn{2}{|r|}{ СР ринку фрінансових послуг та його сегментів } \\
\hline $\mathrm{CPO}$ & $\begin{array}{l}\text { Неприбуткове об'єднання фрінансових установ, створене з метою захисту інтересів } \\
\text { своїх членів та інших учасників ринків фрінансових послуг (РФП) та якому делегуються } \\
\text { відповідними державними органами, що здійснюють регулювання РФП, повноваження } \\
\text { щодо розроблення і впровадження правил поведінки на РФП та/або сертифікації фрахівців } \\
\text { РФП }[9, \text { ст.1, п. 9]. }\end{array}$ \\
\hline $\begin{array}{l}\text { СРО адміністраторів } \\
\text { недержавних } \\
\text { пенсійних фрондів }\end{array}$ & $\begin{array}{l}\text { Неприбуткова організація (непідприємницьке товариство), що створюється з метою } \\
\text { встановлення прооресійних стандартів діяльності } 3 \text { адміністрування недержавних } \\
\text { пенсійних фондів, захисту та представлення інтересів своїх членів, а також учасників } \\
\text { недержавних пенсійних фрондів }[10, \text { ст.1, абз. 34]. }\end{array}$ \\
\hline $\begin{array}{l}\text { СРО кредитних } \\
\text { спілок }\end{array}$ & $\begin{array}{l}3 \text { метою координації своєї діяльності, надання взаємодопомоги та захисту спільних } \\
\text { інтересів кредитні спілки мають право на добровільних засадах створювати асоціації } \\
\text { кредитних спілок }[11, \text { ст. } 24, \text { п. 1]. }\end{array}$ \\
\hline СРО страховиків & $\begin{array}{l}\text { Об'єднання, якому за рішенням Нацкомфінпослуг делеговано окремі повноваження та } \\
\text { інфрормація про яке внесена до реєстру СРО фрінансових установ [12, р. 1, ст. 2, абз. } \\
\text { 4]. Нацкомфрінпослуг може делегувати Об'єднанню такі повноваження: розроблення і } \\
\text { впровадження правил поведінки на ринку страхових послуг; сертифікація фрахівців ринку } \\
\text { страхових послуг [12, р. 1Y, ст.1]. }\end{array}$ \\
\hline $\begin{array}{l}\text { СРО професійних } \\
\text { учасників фрондового } \\
\text { ринку }\end{array}$ & $\begin{array}{l}\text { Неприбуткове об'єднання учасників фондового ринку, що провадять професійну } \\
\text { діяльність на орондовому ринку } 3 \text { торгівлі цінними паперами, управління активами } \\
\text { інституційних інвесторів, депозитарну діяльність, крім депозитаріїв, утворене } \\
\text { відповідно до критеріїв та вимог, установлених Національною комісією } 3 \text { цінних } \\
\text { паперів та фрондового ринку [13, ст. 2, п. 2, абз. 7; р. 1, 6, п. 2, абз. 5]. }\end{array}$ \\
\hline $\begin{array}{l}\text { Зареєстровано три } \\
\text { СРО фрондового } \\
\text { ринку [14] }\end{array}$ & $\begin{array}{l}\text { Асоціація «Українські фондові торговці» - діяльність } 3 \text { торгівлі цінними паперами; } \\
\text { Професійна асоціація ринку капіталу і деривативів - діяльність на фондовому ринку } 3 \\
\text { торгівлі цінними паперами, управління активами інституційних інвесторів, депозитарну } \\
\text { діяльність; Українська асоціація інвестиційного бізнесу - єдина в Україні саморегулююча } \\
\text { недержавна організація, якій держава делегувала частку своїх повноважень, визначивши } \\
\text { їх в Законі [15]. }\end{array}$ \\
\hline \multicolumn{2}{|r|}{ СР землеустрою, архітектурної діяльності та оцінювачів } \\
\hline $\begin{array}{l}\text { СРО у сорері } \\
\text { землеустрою }\end{array}$ & $\begin{array}{l}\text { ГО, які об'єднують фрізичних осіб, визнаних сертифікованими інженерами- } \\
\text { землевпорядниками у порядку, встановленому цим Законом, отримали свій статус } \\
\text { відповідно до вимог цього Закону та здійснюють повноваження } 3 \text { громадського } \\
\text { регулювання землеустрою }[16, \text { ст. } 63] \text {. }\end{array}$ \\
\hline $\begin{array}{l}\text { Зареєстрована СРО } \\
\text { у сорері землеустрою }\end{array}$ & $\begin{array}{l}\text { Всеукраїнська ГО «Всеукраїнська спілка сертифрікованих інженерів-землевпорядників» } \\
{[17] .}\end{array}$ \\
\hline $\begin{array}{l}\text { СРО у сорері } \\
\text { архітектурної } \\
\text { діяльності }\end{array}$ & $\begin{array}{l}\text { Неприбуткові добровільні об'єднання фрізичних та юридичних осіб за відповідним } \\
\text { напрямом підприємницької чи професійної діяльності, які в установленому порядку } \\
\text { набули відповідного статусу [18, ст.1, абз.13]. }\end{array}$ \\
\hline $\begin{array}{l}\text { Зареєстровано } \\
\text { три СРО у сфері } \\
\text { архітектурної } \\
\text { діяльності }\end{array}$ & $\begin{array}{l}\text { Всеукраїнська ГО «Гільдія проектувальників у будівництві» - діяльність інженерів- } \\
\text { проектувальників; ГО «Гільдія інженерів технічного нагляду за будівництвом об'єктів } \\
\text { архітектури» - діяльність інженерів технічного нагляду; Всеукраїнська ГО «Асоціація } \\
\text { експертів будівельної галузі» - профресійна діяльність експертів [19]. }\end{array}$ \\
\hline СРО оцінювачів & $\begin{array}{l}\text { Всеукраїнські ГО, що об'єднують фрізичних осіб, які визнані оцінювачами в порядку, } \\
\text { встановленому цим Законом, отримали свій статус відповідно до вимог цього Закону } \\
\text { та здійснюють повноваження з громадського регулювання оціночної діяльності [20, } \\
\text { ст. 26]. }\end{array}$ \\
\hline $\begin{array}{l}\text { Зареєстровано сім } \\
\text { СРО оцінювачів }\end{array}$ & $\begin{array}{l}\text { ГО «Всеукраїнське об'єднання «Українське товариство оцінювачів»; Всеукраїнська } \\
\text { ГО «Союз експертів України»; ГО «Всеукраїнська асоціація фрахівців оцінки»; ГО } \\
\text { «Всеукраїнська спілка експертів оцінювачів»; ГО «Всеукраїнська спілка оцінювачів; ГО } \\
\text { «Асоціація спеціалістів банківської оцінки України»; Всеукраїнська ГО «Спілка оцінювачів } \\
\text { землі» [21]. }\end{array}$ \\
\hline \multicolumn{2}{|r|}{ СР адвокатури } \\
\hline $\begin{array}{l}\text { Адвокатське } \\
\text { самоврядування }\end{array}$ & $\begin{array}{l}\text { Гарантоване державою право адвокатів самостійно вирішувати питання організації та } \\
\text { діяльності адвокатури в порядку, встановленому цим Законом }[22, \text { ст. } 1, \text { п. 3]. }\end{array}$ \\
\hline
\end{tabular}

ISSN 2312-0967. Фармацевтичний часопис. 2017. № 3 
Організація роботи аптечних підприємств Organization of pharmaceutical structures' work

Продовження табл. 1

\begin{tabular}{|c|c|}
\hline 1 & 2 \\
\hline $\begin{array}{l}\text { Юридична особа } \\
\text { адвокатського } \\
\text { самоврядування }\end{array}$ & $\begin{array}{l}\text { Національна асоціація адвокатів України - недержавна некомерційна професійна } \\
\text { організація, яка об'єднує всіх адвокатів України та утворюється з метою забезпечення } \\
\text { реалізації завдань адвокатського самоврядування [22, ст. 45, п.1, п. 2]. }\end{array}$ \\
\hline Організаційні фрорми & $\begin{array}{l}\text { Конореренція адвокатів регіону, рада адвокатів регіону, рада адвокатів України, з'їзд } \\
\text { адвокатів України [22, ст. 46, п. 1]. }\end{array}$ \\
\hline \multicolumn{2}{|r|}{ СР нотаріату } \\
\hline $\begin{array}{l}\text { Мета професійного } \\
\text { самоврядування } \\
\text { нотаріусів }\end{array}$ & $\begin{array}{l}\text { Об'єднання на професійній основі зусиль нотаріусів для виконання покладених на них } \\
\text { Законом обов'язків і забезпечення їхніх прав, представництво професійних інтересів } \\
\text { нотаріусів у державних органах, органах місцевого самоврядування, на підприємствах, } \\
\text { в установах та організаціях, захист професійних інтересів та соціальних прав нотаріусів, } \\
\text { сприяння підвищенню професійного рівня нотаріусів та надання їм методичної допомоги, } \\
\text { захисту інтересів фрізичних і юридичних осіб при заподіянні їм шкоди внаслідок незаконних } \\
\text { дій або недбалості нотаріуса [23, ст. } 16, \text { абз. 1]. }\end{array}$ \\
\hline Організаційні фрорми & $\begin{array}{l}\text { Просресійне самоврядування нотаріусів здійснюється через Нотаріальну палату України } \\
\text { та її органи [23, ст. 16, абз. 2]. }\end{array}$ \\
\hline \multicolumn{2}{|r|}{ СР аудиту } \\
\hline $\begin{array}{l}\text { Аудиторська палата } \\
\text { України }\end{array}$ & $\begin{array}{l}\text { Незалежна юридична і неприбуткова організація, яка фрормується на паритетних засадах } \\
\text { шляхом делегування доїі складу аудиторів та представників державних органів. Загальна } \\
\text { кількість членів становить двадцять осіб }[24, \text { ст. } 13, \text { абз. } 1-3,7,8]\end{array}$ \\
\hline
\end{tabular}

Що стосується інших сегментів РФП, а саме - адміністраторів недержавних пенсійних орондів, страховиків та кредитних спілок, хоча і передбачена законодавча можливість утворення СРО, проте цей шанс наразі не реалізовано. Робота громадських організацій (ГО) у цих сегментах зосереджена, насамперед, на співпраці з ДР щодо вдосконалення законодавства, захисту інтересів своїх членів тощо.

У свою чергу, у ссрері землеустрою діє одна СРО, архітектурної діяльності - три, а в діяльності оцінювачів - сім таких організацій. Оригінальним є СР адвокатури, яке відбувається шляхом адвокатського самоврядування опосередковано однією юридичною (недержавною, некомерційною і професійною) особою через різні організаційні форми. Схожим є СР нотаріальної діяльності. Значно інший правовий статус СР аудиту, яке здійснюється незалежною, юридичною і неприбутковою організацією, що формується на паритетних засадах з аудиторів та представників ЦОВВ.
Окрім зазначених вище, окремими науковцями до СРО відносять торгово-промислові палати та біржі, діяльність яких здійснюється на підставі дозвільної природи створення та владних фрункцій [25].

В інших видах господарської діяльності, зокрема у фармацевтичній, СР не знайшло законодавчого закріплення. Тому особливого значення набуває проблема взаємодії інститутів громадянського суспільства (ІГС) 3 ЦОВВ України, яка нині відбувається у трьох правових фрормах шляхом участі ІГС у нормотворчій, правозастосовчій і правоохоронній діяльності держави [26]. До ІГС належать громадські об'єднання, релігійні, благодійні організації, профресійні спілки та їх об'єднання, асоціації, організації роботодавців та їх об'єднання, органи самоорганізації населення, недержавні засоби масової інформації, інші непідприємницькі товариства та установи, легалізовані відповідно до законодавства [27].

Особливості взаємодії ІГС з ЦОВВ щодо фрармацевтичної діяльності подано на рисунку 1.

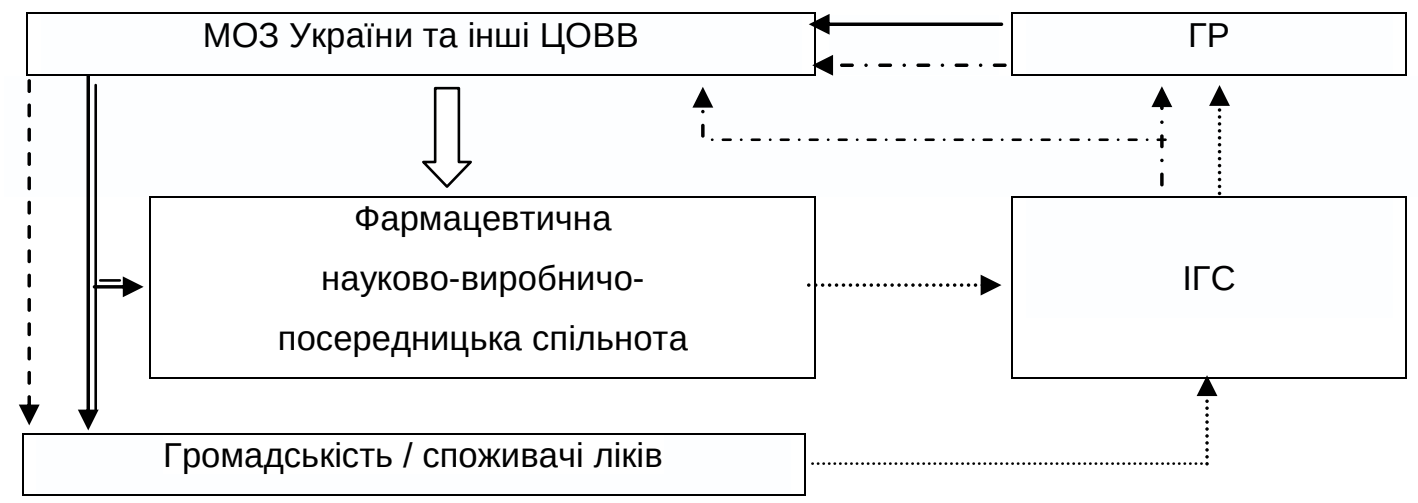

Рис. 1. Модель «як є». Взаємодія ІГС з ЦОВВ щодо фрармацевтичної діяльності: $\Longrightarrow$ - ліцензування діяльності; $\longrightarrow$ - контроль якості фрахової діяльності; $\longrightarrow$ - фрункції консультативно-дорадчі та громадського контролю;

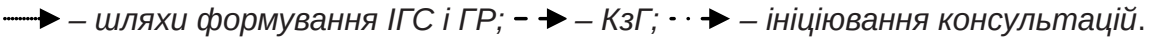

ISSN 2312-0967. Pharmaceutical review. 2017. № 3 
Організація роботи аптечних підприємств Organization of pharmaceutical structures' work

Як видно з даних рисунка 1, основним інструментом ДР фрармацевтичної діяльності є ліцензування. При цьому ЦОВВ фрормують вимоги до УФР, контролюють якість здійснення ними фрахової діяльності і відповідність вимогами, на підставі чого надають право здійснення фрармацевтичної освіти та фрармацевтичного підприємництва.

Для сприяння участі громадськості у фрормуванні та реалізації державної фрармацевтичної політики утворюється тимчасовий консультативно-дорадчий орган при МО3 України (інших ЦОВВ) громадська рада (ГР), до складу якої обираються представники ІГС, у т. ч. представники ІГС, які провадять свою діяльність у фармацевтичному секторі галузі охорони здоров'я.

Основними завданнями ГР є [27]:

- сприяння реалізації громадянами конституційного права на участь в управлінні державними справами;

- здійснення громадського контролю за діяльністю МОЗ України та інших ЦОВВ;

- сприяння врахуванню МОЗ України та іншими ЦОВВ громадської думки під час формування та реалізації державної фрармацевтичної політики.

Для участі в установчих зборах ІГС делегує одного представника, який одночасно є кандидатом на обрання до складу ГР. Склад ГР фрормується на установчих зборах шляхом рейтингового голосування за осіб, які особисто присутні на установчих зборах та кандидатури яких внесені ІГС. Кількісний склад ГР визначається установчими зборами та не може становити більш як 35 осіб. Строк повноважень складу ГР - два роки. До складу ГР може бути обрано не більше одного представника від кожного ІГС. Членство в ГР є індивідуальним.

Для залучення громадян до участі в управлінні державними справами, надання можливості для їх вільного доступу до інформації про діяльність ЦОВВ, а також забезпечення гласності, відкритості та прозо- рості діяльності зазначених органів проводять консультації з громадськістю (КзГ) із питань фрормування та реалізації державної політики.

КзГ організовує і проводить ЦОВВ, який є головним розробником проекту нормативно-правового акта або готує пропозиції щодо реалізації державної, у т. ч. фрармацевтичної, політики. КзГ проводяться у формі публічного громадського обговорення, електронних консультацій з громадськістю (безпосередні форми) та вивчення громадської думки (опосередкована форма).

Ініціювати проведення КзГ шляхом подання відповідних пропозицій ГР або безпосередньо ЦОВВ можуть індивідуально ІГС. Якщо пропозиція щодо проведення КзГ з одного питання надійшла від трьох і більше ІГС, то такі КзГ проводяться обов'язково.

На нашу думку, нині актуальним $€$ запровадження повноцінного фрармацевтичного СР в Україні за умови, що ДР стосуватиметься безпосередньо контролю за фрармацевтичними СРО та не за всіма УФР. При цьому під фрармацевтичною СРО розуміємо неприбуткову організацію, що об'єднує суб'єктів господарської діяльності у фрармацевтичному секторі галузі охорони здоров'я та/або учасників фармацевтичної діяльності, і задачею якої є розробка і встановлення стандартів і правил вказаної діяльності в інтересах не тільки своїх членів, а й споживачів лікарських засобів і фармацевтичних послуг, а також контроль за дотриманням вимог зазначених стандартів і правил та притягнення до відповідальності своїх членів за їх порушення [3].

Використання подібного підходу ДР і СР УФР уможливить заощадження ЦОВВ засобів впливу внаслідок законодавчого делегування фрармацевтичним СРО низки фрункцій державного регулятора та скорочення контрольованих УФР.

Зазначені вище особливості фармацевтичного СР за взаємодії ІГС з ЦОВВ щодо фрармацевтичної діяльності подано на рисунку 2.

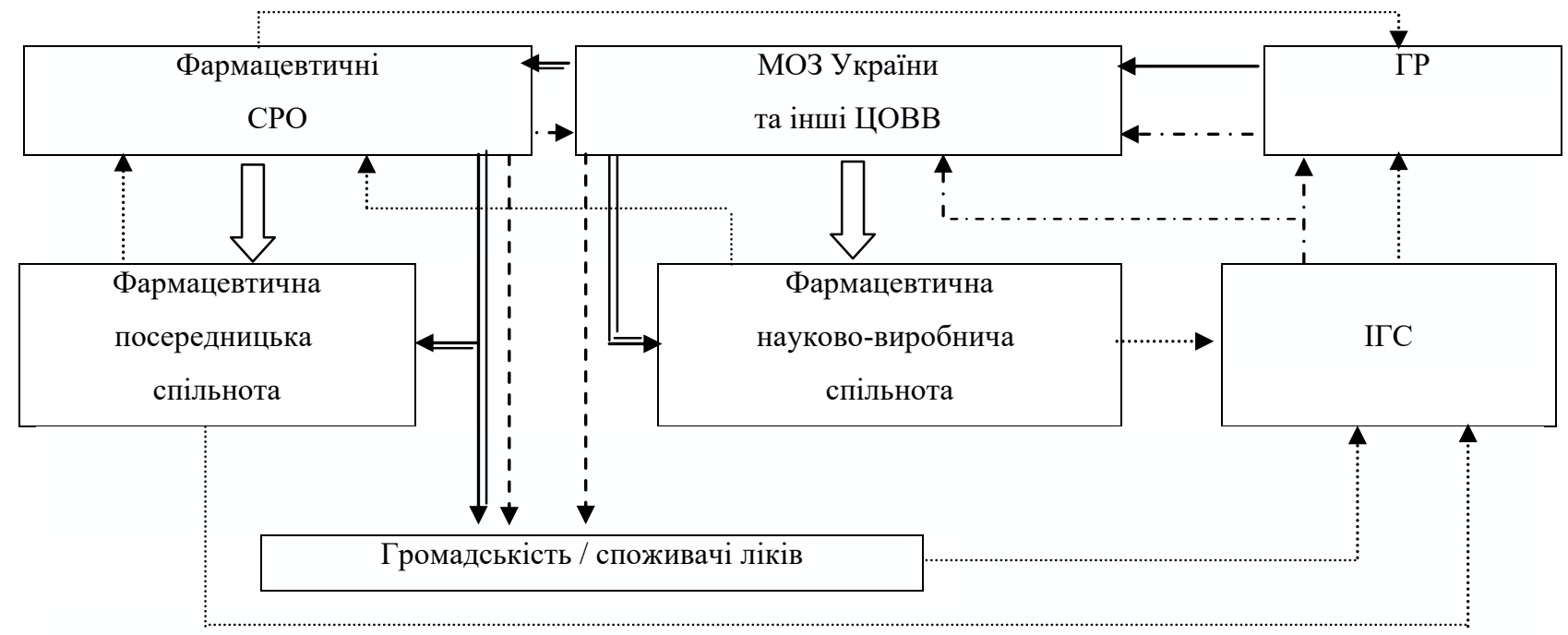

Рис. 2. Модель «як бути». Фармацевтичне СР за взаємодії ІГС з ЦОВВ щодо фрармацевтичної діяльності: умовні позначення на рис. 1.

ISSN 2312-0967. Фармацевтичний часопис. 2017. № 3 
У перспективі ДР і СР УФР потребують базових засад узгодження та гармонізації їх інтересів.

Висновки. На підставі аналізу нормативно-правової бази досліджено особливості СР різних видів господарської діяльності в Україні.

Змодельовано взаємодію ІГС з органами ДР та
СРО щодо фрармацевтичної діяльності від стану «як є» до стану «як бути».

Важливим завданням подальших досліджень є визначення та обґрунтування правового та управлінсько-економічного забезпечення збалансування інтересів ДР і СР УФР.

\title{
СОВРЕМЕННОЕ СОСТОЯНИЕ ЗАКОНОДАТЕЛЬНОГО ОБЕСПЕЧЕНИЯ САМОРЕГУЛИРОВАНИЯ ХОЗЯЙСТВЕННОЙ ДЕЯТЕЛЬНОСТИ И ПЕРСПЕКТИВЫ САМОРЕГУЛИРОВАНИЯ И ГОСУДАРСТВЕННОГО РЕГУЛИРОВАНИЯ ФАРМАЦЕВТИЧЕСКОЙ ДЕЯТЕЛЬНОСТИ В УКРАИНЕ
}

\author{
Б. П. Громовик, О. Б. Панькевич \\ Львовский национальный медицинский университет имени Данила Галицкого \\ hromovyk@gmail.com, pankevych.Iviv@gmail.com
}

Цель работы. Анализ современного состояния законодательного обеспечения процессов саморегулирования (СР) хозяйственной деятельности и перспектив СР и государственного регулирования (ГР) фрармацевтической деятельности.

Материалы и методы. Материалом исследования были нормативно-правовые акты по вопросам СР. Для решения поставленной задачи были применены методы исследования: системный, анализа, сравнения, формализации, обобщения и моделирования.

Результаты и обсуждение. Изучение нормативно-правовой базы в сфрере СР хозяйственной деятельности в Украине показало, что данное положение нашло закрепление в той или иной степени на рынке финансовых услуг и его сегментов, в сфрере землеустройства, архитектурной деятельности, деятельности оценщиков, адвокатов, нотариусов и аудиторов. При этом в других видах хозяйственной деятельности, в частности в фрармацевтической сорере, СР не нашло должного законодательного закрепления. Показано сегодняшнее состояние регулирования фармацевтической деятельности при участии общественных организаций и общественных советов при центральных органах исполнительной власти, а также перспективу ее СР.

Выводы. На основании анализа нормативно-правовой базы исследованы особенности СР различных видов хозяйственной деятельности в Украине. Смоделировано взаимодействие институтов гражданского общества с органами ГР и саморегулируемыми организациями по фрармацевтической деятельности от состояния «как есть» к состоянию «как быть».

Ключевые слова: хозяйственная деятельность; саморегулирование; государственное регулирование; фрармацевтическая деятельность.

\section{THE CURRENT STATE OF ECONOMIC ACTIVITY LEGISLATIVE PROVISION OF SELF-REGULATION AND PROSPECTS OF SELF-REGULATION AND PUBLIC REGULATION OF PHARMACEUTICAL ACTIVITY IN UKRAINE}

\section{B. P. Hromovyk, O. B. Pankevych}

Danylo Halytsky Lviv National Medical University

hromovyk@gmail.com, pankevych.Iviv@gmail.com

The aim of the study. The analysis of current state of self-regulation (SR) legislative maintenance of economic activity and prospects of SR and government regulation (GR) of pharmaceutical activity.

Materials and Methods. Laws and regulations relating to SR were used as materials of research. In order to solve the tasks in hand, next research methods were applied: systemic, analysis, comparison, formalization, generalization and simulation.

Results and Discussion. The study of statutory and regulatory base in the field of SR economic activity in Ukraine showed that this provision was consolidated to a greater or lesser degree in the market of financial services and its segments, in the field of agricultural regulation, architecture activities, appraisers activities, lawyers, notaries and auditors. Herewith, in other types of economic activity, in particular in the pharmaceutical sector, SR was not found the proper legislative consolidation. It was showed the current state of pharmaceutical activity regulation with the participation of public organizations and public councils in the central executive authorities, as well as the perspective of its SR.

ISSN 2312-0967. Pharmaceutical review. 2017. № 3 
Організація роботи аптечних підприємств

Organization of pharmaceutical structures' work

Conclusions. Based on the analysis of the regulatory framework, the features of SR's different types of economic activity in Ukraine are investigated. It was simulated the interaction of civil society institutes with the bodies of GR and selfregulating bodies concerning pharmaceutical activity from the state 'how it is' to the state 'how to be'.

Key words: economic activity; self-regulation; government regulation; pharmaceutical activities.

\section{Список літератури}

1. Господарський кодекс України від 16.01.2003 № 436IV (редакція від 11.06.2017) [Електронний ресурс]. Режим доступу: http://zakon2.rada.gov.ua/laws/show/43615?test=bLNMfnraiH6nrWxAZiNVTrOhHI4dUs80msh8le6. 2. Цивільний кодекс України від 16.01.2003 № 435-IV (редакція від 10.06.2017) [Електронний ресурс]. - Режим доступу: http://zakon2. rada.gov.ua/laws/show/435-15.

3. Громовик Б. П. Термінологічне навантаження саморегулювання фрармацевтичної діяльності / Б. П. Громовик, О. Б. Панькевич // Фармаком. - 2016. № 3, додаток. - С. 100-106.

4. Громовик Б. П. Інституційній вимір міжнародного фармацевтичного саморегулювання / Б. П. Громовик, О. Б. Панькевич // Фарм. часопис. - 2017. - № 1. C. $45-53$.

5. Громовик Б. П. До питання формування i фрункціонування системи фрармацевтичного самоврядування в Україні / Б. П. Громовик, О.Б.Панькевич // «Професійний менеджмент в сучасних умовах розвитку ринку» : матер. доп. V наук.-практ. конфер. 3 міжнар. участю (1 листопада 2016 р.) : збірник. - Х. : Монографр. - 2016. - С. 272-274.

6. Громовик Б. П. Об'єднання підприємств і громадські організації як суб'єкти саморегулювання національного фрармацевтичного ринку / Б. П. Громовик, Л. М. Унгурян // Укр. мед. альманах. - 2012. - № 5 (15). - С. 86 - 89.

7. Сушарина І. В. Визначення пріоритетних напрямків удосконалення державного та суспільного регулювання у фрармації / І. В. Сушарина, А. С. Немченко, В. М. Хоменко // Фарм. часопис. - 2017. - № 1. - С. 38-44.

8. Унгурян Л. М. Роль общественных организаций и субъектов хозяйствования в саморегулировании фрармацевтической практики в Украине / Л. М. Унгурян // Вестник ЮКГФА. - 2014. - № 2. - С. 19-25.

9. Про фрінансові послуги та державне регулювання ринків фрінансових послуг (редакція від 01.01.2017): Закон України від 12.07.2001 № 2664-III [Електронний ресурс]. - Режим доступу: http://zakon2.rada.gov.ua/laws/ show/2664-14.

10. Про недержавне пенсійне забезпечення : Закон України від 09.07.2003 № 1057-IV (редакція від 20.07.2014) : [Електронний ресурс]. - Режим доступу: http://zakon2.rada.gov.ua/laws/show/1057-15.

11. Про кредитні спілки (редакція від 01.01.2016) : Закон України від 20.12.2001 № 2908-ІІІ [Електронний ресурс]. - Режим доступу: http://zakon3.rada.gov.ua/laws/ show/2908-14.

12. Про затвердження Положення про делегування Державною комісією з регулювання ринків фрінансових послуг України окремих повноважень об'єднанню страховиків (редакція від 07.06.2013) : Розпорядження Державної комісії 3 регулювання ринків фрінансових послуг України від 21.08.2008 № 1000 [Електронний ресурс]. - Режим доступу: http://zakon2.rada.gov.ua/laws/ show/z1063-08.

13. Про цінні папери та фрондовий ринок (редакція від 04.06.2017) : Закон України від 23.02.2006 № 3480-IV [Електронний ресурс]. - Режим доступу: http://zakon5. rada.gov.ua/laws/show/3480-15.

14. Саморегулівні організації [Електронний ресурс]. Режим доступу: https://www.nssmc.gov.ua/fund/sro.

15. Про інститути спільного інвестування (пайові та корпоративні інвестиційні фронди) (редакція від 09.12.2015) : Закон України від 05.07.2012 № 5080-VI [Електронний ресурс]. - Режим доступу: http://zakon2. rada.gov.ua/laws/show/5080-17.

16. Про внесення змін до деяких законодавчих актів України щодо дерегуляції господарської діяльності 3 проведення робіт із землеустрою та землеоціночних робіт (редакція від 28.06.2015) : Закон України від 02.10.2012 № 5394-VI [Електронний ресурс]. - Режим допуску: http://zakon2.rada.gov.ua/laws/show/5394-17.

17. Про надання Всеукраїнській громадській організації «Всеукраїнська спілка сертисрікованих інженерівземлевпорядників» статусу саморегулівної організації

Наказ Держгеокадастру від 22.04.2016 № 112 " [Електронний ресурс]. - Режим допуску: http://land.gov. ua/info/nakaz-derzhheokadastru-vid-22-04-2016-112-pronadannia-vseukrainskii-hromadskii-orhanizatsii-vseukrainska-spilka-sertyfikovanykh-inzheneriv-zemlevporiadnykivstatusu-samorehulivnoi-orhaniza/.

18. Про архітектурну діяльність (редакція від 10.06.2017) : Закон України від 20.05.1999 № 687-XIV [Електронний ресурс]. - Режим допуску: http://zakon2. rada.gov.ua/laws/show/687-14.

19. Державний реєстр саморегулівних організацій у сфрері архітектурної діяльності [Електронний ресурс]. - Режим допуску: http://old.minregion.gov.ua/samoregulivni-organizaciyi-576975/reestr-samoregulivnih-organizaciy--785318/.

20. Про оцінку майна, майнових прав та професійну оціночну діяльність в Україні : Закон України від 12.07.2001 № 2658-III (редакція від 16.01.2016) [Електронний ресурс]. - Режим допуску: http://zakon2. rada.gov.ua/laws/show/2658-14.

21. Саморегулівні організації оцінювачів [Електронний ресурс]. - Режим допуску: http://www.spfu.gov.ua/ua/content/spf-estimate-appraisers.html.

22. Про адвокатуру та адвокатську діяльність (редакція від 05.01.2017) : Закон України від 05.07.2012 № 5076VI [Електронний ресурс]. - Режим доступу: http://zakon2. rada.gov.ua/laws/show/5076-17/print1484594237173097. 23. Про нотаріат (редакція від 04.06.2017) : Закон України від 02.09.1993 № 3425-XII [Електронний

ISSN 2312-0967. Фармацевтичний часопис. 2017. № 3 
ресурс]. - Режим допуску: http://zakon2.rada.gov.ua/laws/ show/3425-12/print1484594237173097.

24. Про аудиторську діяльність» (редакція від 01.05.2016) : Закон України від 22.04.1993 № 3125-XII [Електронний ресурс]. - Режим допуску: http://zakon3. rada.gov.ua/laws/show/3125-12.

25. Кочин В. В. Цивільно-правові відносини участі суб'єктів підприємництва у саморегулівних організаціях : монограсрія / В. В. Кочин. - К. : НДІ приватного права підприємництва імені академіка Ф. Г. Бурчака НАПрН України, 2015. - 128 с.

\section{References}

1. Hospodarskyi kodeks Ukrainy vid 16.01.2003 № 436-IV (redaktsiia vid 11.06.2017) Available from: http://zakon2. rada.gov.ua/laws/show/436-15?test=bLNMfnraiH6nrWXAZi NVTrOhHI4dUs80msh8le6.

2. Tsyvilnyi kodeks Ukrainy vid 16.01.2003 № 435-IV (redaktsiia vid 10.06.2017) Available from: http://zakon2. rada. gov.ua/laws/show/435-15.

3. Hromovyk BP, Pankevych OB. [Terminology of self-regulation of pharmaceutical activity]. Farmakom. 2016;3: 100106. Ukrainian.

4. Hromovyk BP, Pankevych OB. [Institutional dimension of international pharmaceutical self-regulation]. Farmatsevt chasop. 2017;1: 45-44. Ukrainian.

5. Hromovyk BP, Pankevych OB. [On the question of formation and functioning of the pharmaceutical self-government in Ukraine]. Kharkiv: National University of Pharmacy; 2016. Ukrainian.

6. Hromovyk BP, Unhurian LM. [Association of enterprises and public organizations as subjects of national self-regulation of the pharmaceutical market]. Ukr. med. almanakh. 2012;5: 86-9. Ukrainian.

7. Susharyna IV, Nemchenko AS, Homenko VM. [Identifying of the priority areas for improving of state and public regulation in pharmacy]. Farmatsevt chasop. 2017;1: 3844. Ukrainian.

8. Unhurian LM. [The role of public organizations and business entities in the self-regulation of pharmacy practice in Ukraine]. Vestnik of the South Kazakhstan State Pharmaceutical Academy. 2014;2: 19-25.

9. Zakon Ukrainy vid 12.07.2001 № 2664-III "Pro finansovi posluhy ta derzhavne rehuliuvannia rynkiv finansovykh posluh" (redaktsiia vid 01.01.2017) Available from: http://zakon2.rada.gov.ua/laws/show/2664-14.

10. Zakon Ukrainy vid 09.07.2003 № 1057-IV «Pro nederzhavne pensiine zabezpechennia» (redaktsiia vid 20.07.2014) Available from: http://zakon2.rada.gov.ua/ laws/show/1057-15.

11. Zakon Ukrainy vid 20.12.2001 № 2908-III «Pro kredytni spilky» (redaktsiia vid 01.01.2016) Available from: http://zakon3.rada.gov.ua/laws/show/2908-14.

12. Rozporiadzhennia Derzhavnoi komisii z rehuliuvannia rynkiv finansovykh posluh Ukrainy vid 21.08.2008 № 1000 «Pro zatverdzhennia Polozhennia pro delehuvannia Derzhavnoiu komisiieiu z rehuliuvannia rynkiv finansovykh posluh Ukrainy okremykh povnovazhen obiednanniu strakhovykiv» (redaktsiia vid 07.06.2013): Available from: http://
26. Роз'яснення Міністерства юстиції України від 03.02.2011 «Взаємодія держави та інститутів громадянського суспільства» [Електронний ресурс]. - Режим допуску: http://zakon2.rada.gov.ua/laws/show/ n0018323-11.

27. Про забезпечення участі громадськості у формуванні та реалізації державної політики (редакція від 29.05.2015) : Постанова КМ України від 03.11.2010 № 996 [Електронний ресурс]. - Режим допуску: http://zakon2.rada.gov.ua/laws/show/996-2010-\%D0\%BF.

zakon2.rada.gov.ua/laws/show/z1063-08.

13. Zakon Ukrainy vid 23.02.2006 № 3480-IV "Pro tsinni papery ta fondovyi rynok" (redaktsiia vid 04.06.2017) Available from: http://zakon5.rada.gov.ua/laws/show/3480-15.

14. Self-regulation organization. Available from: https:// www.nssmc.gov.ua/fund/sro.

15. Zakon Ukrainy vid 05.07.2012 № 5080-VI «Pro instytuty spilnoho investuvannia (paiovi ta korporatyvni investytsiini fondy)» (redaktsiia vid 09.12.2015) Available from: http:// zakon2.rada.gov.ua/laws/show/5080-17.

16. Zakon Ukrainy vid 02.10.2012 № 5394-VI «Pro vnesennia zmin do deiakykh zakonodavchykh aktiv Ukrainy shchodo derehuliatsii hospodarskoi diialnosti z provedennia robit iz zemleustroiu ta zemleotsinochnykh robit» (redaktsiia vid 28.06.2015) Available from: http://zakon2.rada. gov.ua/laws/show/5394-17.

17. Nakaz Derzhheokadastru vid 22.04.2016 № 112 "Pro nadannia Vseukrainskii hromadskii orhanizatsii «Vseukrainska spilka sertyfikovanykh inzheneriv-zemlevporiadnykiv» statusu samorehulivnoi orhanizatsii" Available from: http://land.gov.ua/info/nakaz-derzhheokadastru-vid22-04-2016-112-pro-nadannia-vseukrainskii-hromadskiiorhanizatsii-vseukrainska-spilka-sertyfikovanykh-inzhenerivzemlevporiadnykiv-statusu-samorehulivnoi-orhaniza/.

18. Zakon Ukrainy vid 20.05.1999 № 687-XIV «Pro arkhitekturnu diialnist» (redaktsiia vid 10.06.2017) Available from: http://zakon2.rada.gov.ua/laws/show/687-14.

19. Derzhavnyi reiestr samorehulivnykh orhanizatsii u sferi arkhitekturnoi diialnosti. Available from: http://old.minregion.gov.ua/samoregulivni-organizaciyi-576975/reestr-samoregulivnih-organizaciy--785318/.

20. Zakon Ukrainy vid 12.07.2001 № 2658-III «Pro otsinku maina, mainovykh prav ta profesiinu otsinochnu diialnist $v$ Ukraini» (redaktsiia vid 16.01.2016) Available from: http:// zakon2.rada.gov.ua/laws/show/2658-14.

21. Samorehulivni orhanizatsii otsiniuvachiv. Available from: http://www.spfu.gov.ua/ua/content/spf-estimate-appraisers.html.

22. Zakon Ukrainy vid 05.07.2012 № 5076-VI "Pro advokaturu ta advokatsku diialnist" (redaktsiia vid 05.01.2017) Available from: http://zakon2.rada.gov.ua/laws/show/507617/print1484594237173097.

23. Zakon Ukrainy vid 02.09.1993 № 3425-XII «Pro notariat» (redaktsiia vid 04.06.2017) Available from: http://zakon2. rada.gov.ua/laws/show/3425-12/print1484594237173097.

24. Zakon Ukrainy vid 22.04.1993 № 3125-XII «Pro audy-

ISSN 2312-0967. Pharmaceutical review. 2017. № 3 
Організація роботи аптечних підприємств

Organization of pharmaceutical structures' work

torsku diialnist» (redaktsiia vid 01.05.2016) Available from: http://zakon3.rada.gov.ua/laws/show/3125-12.

25. Kochyn VV. [Civil-legal relations of participation of business entities in self-regulatory organizations]. Kyiv: Academician F. H. Burchak Scientific Research Institute of Private Law and Entrepreneurship of NALS of Ukraine; 2015. Ukrainian.

26. Roziasnennia Ministerstva yustytsii Ukrainy vid
03.02.2011 «Vzaiemodiia derzhavy ta instytutiv hromadianskoho suspilstva» Available from: http://zakon2.rada.gov. ua/laws/show/n0018323-11.

27. Postanova KM Ukrainy vid 03.11.2010 № 996 «Pro zabezpechennia uchasti hromadskosti u formuvanni ta realizatsii derzhavnoi polityky» (redaktsiia vid 29.05.2015) Available from: http://zakon2.rada.gov.ua/laws/show/9962010-\%D0\%BF. 